Srđan Milićević ${ }^{1}$ Miroljub Nikolić ${ }^{2}$ Slobodan Cvetanović ${ }^{3}$
JEL: L73

DOI: $10.5937 /$ industrija45-14579

UDC: 674:339.137.2(497.11)"1994/2015" 339.564(497.11)

Original Scientific Paper

\title{
The Competitivenes of Wood Processing Industry in the Republic of Serbia During The Period 1995-2015
}

\author{
Article history: \\ Received: 18 July 2017 \\ Sent for revision: 25 July 2017 \\ Received in revised form: 24 August 2017 \\ Accepted: 25 August 2017 \\ Available online: 10 October 2017
}

\begin{abstract}
The paper considers the competitiveness of wood processing industry in the Republic of Serbia in the period 1995-2015 by using six partial indicators of competitiveness: Revealed comparative advantage (RCA), Competitiveness growth index (RCA1), Index of net business performance (RCA2), Index of contribution to the trade balance (CTB), Grubel-Lloyd index (GLI) and Michaely index (MI). The research reveals that the values of RCA were positive in all years, which points to comparative advantage of wood processing industry on the domestic market. Since RCA1 has significantly higher value than one, it means that it is highly competitive on international market as well. Positive values of RCA2 in the period 1995-2015 speak of the contribution of this branch to international economic balance. The indicator RCA2 is connected with the CTB index, which points to the contribution of the sector in formation of active national trade balance and economic growth. The average value of CTB index of wood processing industry in Serbia and positive annual values of CTB of wood processing industry show that the contribution in the total trade balance of the sector is positive. The course of GLI values points to the loss of capabilities of the sector to create the surplus of national trade balance. Finally, positive annual values of MI confirmed the competitiveness of domestic wood processing industry, but at the same time its low specialisation. Taken as a whole, the weakness of competitiveness of wood processing industry in Serbia can be seen in the fact that its competitive advantage is visible in its favourable price, not in manufacturing complex products with high value added. The aim of the paper is to investigate whether
\end{abstract}

\footnotetext{
${ }^{1}$ Metropolitan University, Belgrade

2 Ministry of Economy, Serbia

${ }^{3}$ University of Niš, Faculty of Economics, slobodan.cvetanovic@eknfak.ni.ac.rs 
Milićević S. et al.:The Competitivenes of Wood Processing Industry in the Republic of..

Serbian wood processing industry has comparative precedence on domestic and international markets and whether the structure of exchange is positive, i.e. whether appropriate specialisation of production and export exists or the focus should shift onto more complex products and value added.

Keywords: sector competitiveness, partial indicators of competitiveness, wood processing industry, Serbia

\section{Konkurentnost drvne industrije Republike Srbije u periodu 1995-2015}

Apstrakt: U radu je sagledavana konkurentnost drvne industrije Republike Srbije u periodu 1990-2015. korišćenjem šest parcijalnih pokazatelja konkurentnosti: Indikator otkrivene komparativne prednosti (RCA), Indeks rasta konkurentnosti (RCA1), Indeks neto poslovnih performansi (RCA2), Indeks doprinosa trgovinskom bilansu (CTB), Grubel-Lloydov indeks (GLI) i Michaely indeks (MI). Istraživanje je pokazalo da su u svim godinama vrednosti RCA bile pozitivne što ukazuje na komparativnu prednost drvne industrije na domaćem tržištu. Budući da RCA1 ima značajno veću vrednost od jedan, proizilazi da postoji njena visoka konkurentnost na međunarodnom tržištu. Pozitivne vrednosti RCA2 u periodu 1995-2015. govore o doprinosu ove grane spoljnotrgovinskom bilansu privrede. Indikator RCA2 je povezan sa indeksom CTB koji ukazuje na doprinos sektora u formiranju aktivnog nacionalnog trgovinskog bilansa $i$ ekonomskom rastu privrede. Prosečna vrednost CTB indeksa i pozitivne godišnje vrednosti CTB drvne industrije pokazuju da je doprinos sektora u ukupnom trgovinskom bilansu pozitivan. Kretanje vrednosti GLI ukazuje na gubitak sposobnosti sektora da stvori višak nacionalnog trgovinskog bilansa. Konačno, pozitivne godišnje vrednosti MI potvrdile su konkurentnost domaće drvne industrije, ali $i$ njenu nisku specijalizaciju. U celini uzevši, slaba strana konkurentnosti drvne industrije Srbije ogleda se u činjenici da se njena konkurentna prednost ogleda u povoljnoj ceni, a ne u proizvodnji kompleksnih proizvoda visoke dodate vrednosti. Cilj ovog rada je da istraži da li drvna industrije Srbije ima komparativnu prednost na domaćem i međunarodnom tržištu, da li je strktura razmene pozitivna, odnosno da li postoji odgovarajuća specijalizacija proizvodnje i izvoza ili se treba više usmeriti na proizvode više složenosti $i$ dodate vrednosti.

Ključne reči: sektorska konkurentnost, parcijalni pokazatelji konkurentnosti, drvna industrija, Srbija 
Milićević S. et al.:The Competitivenes of Wood Processing Industry in the Republic of..

\section{Introduction}

Competitiveness is one of the most powerful concepts in contemporary economic theory (Garelli, 2004). It shows the capability to achieve success on markets, where the participants who implement available knowledge and abilities in products and services meet. Competitiveness is a multidimensional phenomenon, and as such is necessarily present at the level of an enterprise, an economic branch or a country as a whole. The level at which it is investigated is a significant aspect of analysis of the concept of competitiveness (Kitson, Martin \& Tyler, 2004; Annoni \& Kozovska, 2010).

A number of authors think that while investigating the phenomenon of national competitiveness, the focus should not be on economy as a whole, but on certain industries and industrial segments (Cho \& Moon, 2000). In that context, the competitiveness of industry speaks of its ability to create value added in comparison to the same productive sectors in other countries, the ability to attract the factors of production in relation to other industries within the same country or other countries, as well as the ability to adjust industry to social-economic conditions (Toming, 2011).

Wood processing industry is increasingly multi-sector activity with offer of wood products as a renewable resource. Wood products can be recycled and repeatedly used and thus be a renewable source of energy. Wood products are biodegradable and can be utilised as a substitution for non-renewable resources.

Wood processing industry is a manufacturing activity which considerably contributes to creation of value added, employment and export. Wood processing enterprises are characterised by resourcefully intensive, exportoriented production whose structure is traditionally predominated by the products of lower technological complexity, mostly characterised by costing competitiveness on both domestic and world markets. A significant source of competitive priority is management of expenses, while the strategies of differentiation and focusing are less present.

Wood processing industry is a considerable part of manufacturing industry and a significant lever of growth in Republic of Serbia. Wood processing industry has a long tradition in Serbia, which is logical, bearing in mind sufficient wood assortment as input raw material in the process of manufacturing. It is a domain in which the country can achieve competitive advantage at regional and global level, realise positive trade balance and contribute to economic and employment growth (Sujová, Hlaváčková \& Marcineková, 2015). 
Milićević S. et al.:The Competitivenes of Wood Processing Industry in the Republic of..

Increasingly pronounced globalisation and openness of domestic economy imposes new challenges for the enterprises in wood processing industry. The products of wood processing industry in the Republic of Serbia have become the subject of international exchange and are influenced by global competitiveness, which implies uninterrupted testing of technological characteristics, product quality and price on both domestic and foreign markets. Domestic wood processing enterprises are forced to make complex structural changes to be able to manufacture the products competitive in price and quality by the criteria of global market.

The sources of competitiveness of wood processing enterprises which based their production on the economy of scope and low costs of manufacturing are no longer sufficient for their success in highly competitive and dynamic business environment. Business and development which is based only on the strategy of low costs and cheap final products is increasingly less sustainable for the enterprises which aspire towards improvement of competitiveness. Wood processing enterprises have to develop new business strategies (manufacturing and marketing of products) in order to create higher value added and provide sustainable competitive benefits. In order to improve competitiveness, they have to increasingly focus on differentiation of products through the development and introduction of new products which create higher value added and/or decrease total costs of production.

Great changes in global environment which occurred as a result of globalisation of market (appearance of global competitiveness, primarily from the countries with rapid growth and/or abundance of natural resources such as China, Russia, India etc.) changed the costs of energy, development of technology, new demands of consumers and climatic changes significantly altered business conditions, competitive position and sources of competitive advantages of wood processing enterprises. However, the phenomenon of competitiveness of wood processing enterprises as a significant factor of development of wood processing industry, and economy as a whole draws poor attention of academic and professional audience in Serbia.

The subject of research in this paper is the competitiveness of wood processing industry in Serbia in the period from 1995-2015. The products of wood industry are considerably the subject of international trade, which is in open economy the reason for permanent testing of their technological characteristics, quality and prices on both domestic and foreign markets.

The paper includes six chapters. After the introductory chapter the position of wood processing industry in the Republic of Serbia on global market is analysed. The third chapter discusses the concept of competitiveness at the level of a branch and presents the most frequently used indicators of this type of competitiveness. The fourth section shows the results of the research and presents the indicators of competitiveness of wood processing industry in 
Milićević S. et al.:The Competitivenes of Wood Processing Industry in the Republic of..

Serbia in the period 1995-2015. The fifth chapter discusses the obtained results of research. Finally, the sixth section sublimates certain conclusions.

\section{The status of wood processing industry in Serbia on global market}

The status of wood processing industry in Serbia on global market can be distinguished through indicators which consider participation of wood processing industry in total foreign trade exchange, while the success of wood industry on foreign markets can be followed by investigating exporting performance of the sector.

In the period 1995-2015, wood processing industry in Serbia made the greatest export in 2014 and 2015, and significant growth was recorded in 1997 (Table 1). The export in wood processing industry in Serbia rose from 2006 - 2009, when it was interrupted, to recover in 2010 and achieve the highest value in 2011. Import mostly followed the dynamics of export until 2009, when the import, after a significant fall in relation to 2008 stagnated, while the export recovered and constantly increased in the following years. Wood processing industry in the Republic of Serbia had the greatest extent of foreign exchange in 2008, after permanent growth which, with a slight slowdown in 2005 began in 2001; the growth of foreign exchange in wood processing industry was significantly faster from 2006-2008. After a sharp fall in 2009 , foreign trade activity of wood processing industry continued its cyclic growth, and in 2014 it approached its highest value from 2008.

Table 1: Export characteristics of wood processing industry in the Republic of Serbia in the period 1995-2015.

\begin{tabular}{|c|c|c|c|c|c|c|c|c|c|}
\hline & $\mathbf{1 9 9 5}$ & $\mathbf{2 0 0 0}$ & $\mathbf{2 0 0 5}$ & $\mathbf{2 0 1 0}$ & $\mathbf{2 0 1 1}$ & $\mathbf{2 0 1 2}$ & $\mathbf{2 0 1 3}$ & $\mathbf{2 0 1 4}$ & $\mathbf{2 0 1 5}$ \\
\hline Export * $^{*}$ & 81.728 & 102.475 & 158.697 & 350.890 & 434.762 & 445.520 & 528.504 & 575.064 & 575.590 \\
\hline Import * $^{*}$ & 62.481 & 84.524 & 187.284 & 312.846 & 342.619 & 321.964 & 365.415 & 355.172 & 321.247 \\
\hline Foreign trade * & 144.209 & 186.999 & 345.982 & 663.736 & 777.381 & 767.484 & 893.919 & 930.237 & 896.837 \\
\hline Trade balance * $^{2}$ & 19.248 & 17.951 & -28.587 & 38.043 & 92.143 & 123.556 & 163.088 & 219.892 & 254.343 \\
\hline $\begin{array}{c}\text { Coverage of } \\
\text { import by export }\end{array}$ & 131 & 121 & 85 & 112 & 127 & 138 & 145 & 162 & 179 \\
\hline $\begin{array}{c}\text { Participation in } \\
\text { export of the } \\
\text { economy ** }\end{array}$ & 5,6 & 6,3 & 3,3 & 3,6 & 3,7 & 4,0 & 3,6 & 3,9 & 4,3 \\
\hline $\begin{array}{c}\text { Participation in } \\
\text { import of the } \\
\text { economy ** }\end{array}$ & 2,7 & 2,6 & 2,1 & 1,9 & 1,7 & 1,7 & 1,8 & 1,7 & 1,8 \\
\hline
\end{tabular}

Note: * in thousands of USD, ${ }^{* *}$ in $\%$.

Source: Calculated by the author, based on the data obtained from UNCTADStat, n.d.

Industrija, Vol.45, No.3, 2017 
Milićević S. et al.:The Competitivenes of Wood Processing Industry in the Republic of..

Wood processing industry in the Republic of Serbia recorded the most favorable foreign trade balance in 2015 , and achieved surplus in the period 1995-2001. In the period from 2002-2009 foreign trade balance of wood processing industry was negative, and the deficit was especially pronounced in 2008, when the import was 1.3 times higher than export.

The participation of wood processing industry in total export had a cyclic trend, and was $4.8 \%$ on average. The greatest participation of wood processing industry export in total export was in 1997 (13.0\%), and the lowest in 2006 (3.6\%). After the minimum value which was recorded in 2006, the participation of wood industry in total export in the following ten-year-period ranged from $3.5 \%-4.5 \%$, while the participation of $4.3 \%$, which was recorded in 2015, was equal to the participation of wood industry in 2002 (Figure 1).

Figure 1: The status of wood processing industry in foreign trade exchange of the Republic of Serbia

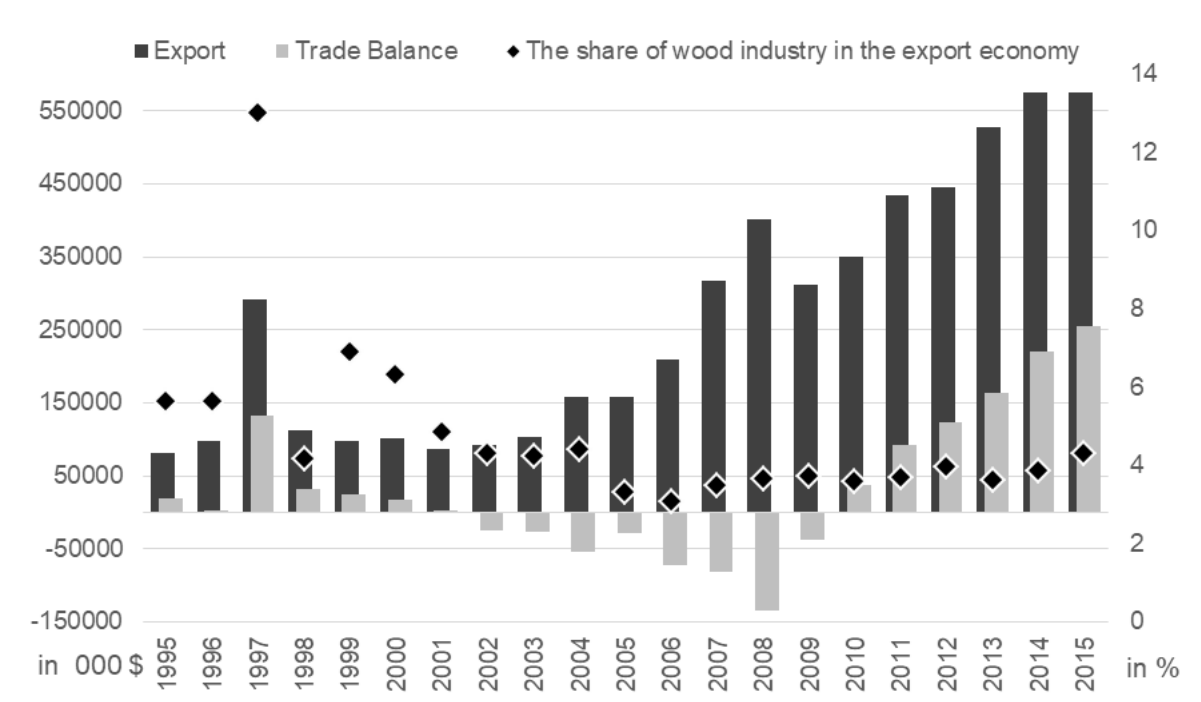

Source: Calculated by the author, based on the data obtained from UNCTADStat, n.d.

From 1995-2015, wood processing industry participated in import with $2.2 \%$ on average; the highest participation was in 1997 (3.9\%), and the lowest in 2011, 2012 and $2014(1.7 \%)$. In 2015 the participation of wood processing industry in the import amounted $1.8 \%$ which was slightly lower in comparison to the participation in 1998 (1.9\%).

During the observed twenty-year-period, the value of exported products of wood industry in the Republic of Serbia exceeded the value of imported 
Milićević S. et al.:The Competitivenes of Wood Processing Industry in the Republic of..

products in the same sector (surplus), so that the coverage of import by export was $115 \%$ on average, i.e. the export was $15 \%$ higher than the value of import. The greatest coverage of import by export in wood industry was in 2015 (179\%), and the lowest was in 2004, 2005 and 2008, when the export in wood industry covered only $75 \%$ of the import.

\section{Competitiveness on branch level: concept and methods}

Besides variety of definitions of competitiveness, most economists agree in their judgement that the twenty-first century is the period of global or international competitiveness of countries, primarily thanks to the globalisation process. In economic literature, a great number of authors and institutions differently define national competitiveness or country competitiveness. Numerous definitions show diversity and the scope of concept of competitiveness and reflect its development (Siggel, 2007: 2-5).

Speaking of competitiveness of national economy or its part, one should not forget that the focus of economic competitiveness is at the level of an enterprise. The value is created at the level of enterprise, while the competitiveness of a country, i.e. particular economic branch is only the reflection of capability of its economic subjects to be successfully involved in international economic processes. Shortly, the improvement of competitiveness of a country is based on a permanent growth of competitiveness of its enterprises. In this way, the notion of national (international) competitiveness is very close to the concept of competitiveness of an enterprise, despite differences in the aims between an enterprise and national economy (Grauwe, 2010).

In practical business today, competitive benefit is increasingly based on both low cost (rationalisation of production and economy of scope) and differentiation of products (investment in research and development, technologies, innovativeness, quality, marketing or brand creation). Together with numerous activities of an enterprise, these benefits lead to three generic strategies for achievement of exceptional results in a certain segment of manufacturing: (1) cost leadership, (2) differentiation and (3) focusing. Each generic strategy implies various approaches to realisation of a specific type of competitive benefit and strategic objective. The selection of a strategy by an enterprise depends on numerous factors, especially on the structure of branch in which it operates (Porter, 2007: 22-30).

There is not only one comprehensive indicator of the level of competitiveness of economy as a whole or its specific parts. Some indicators are related only to economy as a whole, while others can measure both competitiveness of 
Milićević S. et al.:The Competitivenes of Wood Processing Industry in the Republic of..

economy as a whole and at lower levels of economic structure. A great number of indicators for identification and measurement of competitiveness are widely used and developed in practice and show specific combination of characteristics of competitiveness of the selected manufacturing sector or a country as well (Han, Wen \& Kant, 2009). The indicators of competitiveness can be classified in two basic groups: the indicators directed towards results (outcomes) and indicators directed towards determinants (Dieter \& Englert, 2007).

The indicators directed towards results enable the detection of additional (expost) competitive position and are used for determination of competitiveness at the level of sector and on international market. With their significance, the following indicators of competitiveness of a country and specific industrial branches are pronounced: Revealed comparative advantage - RCA, Competitiveness growth index - RCA1, Index of net business performanceRCA2, Index of contribution to the trade balance - CTB, Grubel-Lloyd index GLI, Michaely index - MI (Sujová et al., 2015)

RCA is the most often used indicator of competitiveness. It measures comparative advantage of a country in international exchange of a certain product (or production in certain industry) (Rybakovas, 2009). It appears in several forms. In accordance with the methodology of International Trade Centre UNCTAD and WTO, the processing of analysis in the domain of trade development considers the difference between net export, the existing specialisation, trade deficit and theoretical net export. It is not involved in the analysis of reasons which lead to comparative advantages of a certain country in the international trade, but detects the presence of comparative advantages based on the data on export results of specific product groups in world export, and by comparing various periods determines whether a change in the structure of export is realised, and whether comparative advantages change in favour of product groups with more or less value added.

The formula for calculation of indicators of comparative advantages was developed by Bella Balassa, who presented the so-called "Balassa index" or "Revealed comparative advantage" (RCA) in 1965, which was later adjusted and modified (Hinloopen \& Marrewijk, 2001). This index is still most frequently used method for measuring comparative advantages of economies of certain countries in the international exchange of goods, although it suffers both theoretical foundation and empirical distribution weaknesses (Amighini, Leone \& Rabellotti 2011). Balassa index is an indicator which shows comparative advantage or the lack of export and its competitive capability. The RCA indicates whether a country is in the process of extending the products in which it has a trade potential, as opposed to situations in which the number of products that can be competitively exported is static. It can also provide useful information about potential trade prospects with new partners. Countries with 
Milićević S. et al.:The Competitivenes of Wood Processing Industry in the Republic of..

similar RCA profiles are unlikely to have high bilateral trade intensities unless intraindustry trade is involved. RCA measures, if estimated at high levels of product disaggregation, can focus attention on other nontraditional products that might be successfully exported. The RCA index of country $i$ for product $j$ is often measured by the product's share in the country's exports in relation to its share in world trade:

$$
\operatorname{RCA}_{i j}=\left(x_{i j} / X_{i t}\right) /\left(x_{w j} / X_{w t}\right),
$$

where $x_{i j}$ and $x_{w j}$ are the values of country i's exports of product $j$ and world exports of product $j$ and where $X_{i t}$ and $X_{w t}$ refer to the country's total exports and world total exports. A value of less than unity implies that the country has a revealed comparative disadvantage in the product. Similarly, if the index exceeds unity, the country is said to have a revealed comparative advantage in the product (Trade Indicators - World Integrated Trade Solution (WITS), n.d.)

Balassa RCA formula can be modified to detect competitiveness of product groups within the industry, i.e. to determine intrasectoral competitiveness. In this way the following formula is obtained: $R C A=\ln [(x i j / m i j) /(X i j / M i j)]$, whereby xij is export of product group "i" in sector "i" and country "j", mij is a value of import of product group "i" in sector " $i$ " and country " $\mathrm{j}$ ", Xij is export of sector "i", country "i" and Mij is import of sector "i" and country "j".

When $\mathrm{RCA}<0$, then it points to comparative shortcomings of products; when $\mathrm{RCA}>0$, then it points to comparative advantages in export of products, or branch to which the product belongs, and when $\mathrm{RCA}=1$, it points that both product and branch are internationally competitive (Klodt, 1993).

A more significant modification of Balassa RCA formula was done by Austrian Institute for Economic Research - WIFO Vienna, in order to provide expression of competitiveness at the national level (Aiginger \& Landesman, 2002). By using WIFO methodology, Competitiveness growth index - RCA1 is obtained, which provides measuring of competitiveness of economy on regional and global markets.

Competitiveness growth index - RCA1 is obtained by comparison of export of certain product group in total export of certain country in relation to the value of global export of the observed product group and total global value of export, and is calculated by using the formula RCA $1=(x \mathrm{ij} / \mathrm{Xj})(\mathrm{Xi} / \mathrm{X}) . \mathrm{X}_{\mathrm{j}}$ where $\mathrm{X}_{\mathrm{i}}$ denotes the value of total export of the country $j, X_{i}$ refers to world export of the sector $i$, and $\mathrm{X}$ is world export or export. When RCA $>1$, then it shows uncovered comparative advantage of branches on global market, while when $\mathrm{RCA}<1$, then a product group has no competitive capability on the relevant market. 
Milićević S. et al.:The Competitivenes of Wood Processing Industry in the Republic of..

Index of net business performance- RCA2 quantifies the contribution of a particular sector to formation of active trade balance, i.e. comparative advantage of branch or product export and its competitive capability (Balassa, 1965). It is obtained as a difference between export and import of a sector and sum of export and import of those sectors expressed in percentage, calculated by using the formula $\mathrm{RCA} 2=(\mathrm{xij}-\mathrm{mij}) /(\mathrm{xij}+\mathrm{mij})$. When $\mathrm{RCA} 2=-1$, it means that no export exists $\left(x_{i j}=0\right)$; when $-1<\mathrm{RCA} 2<0$ it points to comparative shortcomings, $\mathrm{RCA} 2=0$ denotes export $=$ import; when $0<$ RCA2 $<1$ it points to uncovered comparative advantages and when RCA2 = 1 , it means that no import exists $\left(m_{i j}=0\right)$.

Index of contribution to the trade balance - CTB measures the contribution of particular sectors to national trade balance. It is obtained as a difference between the real and expected balance of economy (Melišek, 2012) and is calculated by using the formula

$$
\mathrm{CTB}=\frac{x_{i j}-m_{i j}}{X_{j}+M_{j}}-\frac{X_{j}-M_{j}}{X_{j}+M_{j}} * \frac{x_{i j}+m_{i j}}{X_{j}+M_{j}} * 100
$$

The left side of equation denotes real trade balance of a branch which is pondered by its participation in total foreign trade exchange of a country which is intersectoral trade. The right side of equation measures the expected trade balance of a sector, provided that each sector contributes to total trade balance according to its participation in total trade. The difference between the real and the expected trade balance measures specific contribution to total trade balance. When CTB $>0$, it means that real surplus is higher than expected and relative trade deficit is lower than expected, so that the sector makes positive contribution to total trade balance; when CTB $<0$, it means that the sector has negative contribution to total trade balance, and that real results in comparison to the expected are negative or insufficient.

Grubel-Lloyd index - GLI is most often applied in quantification of intraindustrial trade, i.e. capacity of countries in the utilisation of economies of scope (Grubel \& Lloyd, 1971). GLI measures export capacity at macroeconomic level, i.e. analyses the degree of presence of product with intersectoral character in foreign trade, whereby higher level of presence points to higher level of national competitiveness. The index is modified for the assessment at the level of a branch and its calculation shows a degree of presence of commodities in intersectoral foreign trade exchange of a country.

It is calculated by using the formula: 
Milićević S. et al.:The Competitivenes of Wood Processing Industry in the Republic of..

$$
G L I=1-\frac{\frac{x_{i j}}{X_{j}}-\frac{m_{i j}}{M_{i j}}}{\frac{x_{i j}}{X_{i j}}+\frac{m_{i j}}{M_{j}}} .
$$

The value of $\mathrm{GLI}$ ranges within the interval from 0 to $1(0<\mathrm{GLI}<1)$. Its closeness to one shows an approximately the same structure of production and export, i.e. greater complementariness of the two markets and vice versa. The comparative value should be the average value of GLI for all sectors in a country or global value of a given sector (product group)

Michaely index - MI shows the level of specialisation of a country in product group or branch (Michaely, 1962). It measures the participation of product group in total national export and participation of product group in total national import. It is calculated by using the formula:

$$
M I=\frac{x_{i j}}{\sum_{i=1}^{n} X_{j}}-\frac{m_{i j}}{\sum_{i=1}^{n} M_{j}}
$$

When the value of index ranges $0<\mathrm{Ml}<1$ it points to a certain degree of specialisation of a country in product group, and when the value ranges $-1<\mathrm{MI}$ $<0$ it points to insufficient specialisation of a country in product group.

Coefficient of correlation $-\mathbf{r}$ is a statistical method of correlation analysis which measures the degree of interdependence of two connected variables and is calculated by using the formula:

$$
\operatorname{Correl}(X, Y)=r=\frac{\sum(x-\bar{x})(y-\bar{y})}{\sqrt{\sum(x-\bar{x})^{2} \sum(y-\bar{y})^{2}}}
$$

where $\mathrm{x}$ is dependent and $\mathrm{y}$ is independent variable.

The strength of the connection between variables is expressed by numerical values of correlation coefficient which range from +1.0 to -1.0 , so that the closer the coefficients are to 1 , the stronger congruity between variables is.

Since there is no generally accepted synthetic indicator of the achieved level of competitiveness of an industrial branch, the aim is to find the most suitable answer to the issue of attained level of competitiveness of wood processing industry in the Republic of Serbia in the observed time period, by using the most significant particular indicators.

The competitiveness of wood processing industry in the Republic of Serbia is in this paper observed by using most significant particular indicators of industrial competitiveness at the level of activity, i.e. branch. The calculation of separate indicators respects the fact that in the framework of wood processing industry, raw wood is processed and then further manufactured 
Milićević S. et al.:The Competitivenes of Wood Processing Industry in the Republic of..

depending on diverse stages of finalisation. In that sense, according to Standard International Trade Classification (SITC) Revision 3, wood processing industry includes the following sections:

- 24 - Cork and wood,

- 63 - Cork and wood manufactures, excluding furniture,

- 821 - Furniture \& parts

The input data for the assessment of competitiveness of word processing industry in Serbia for the period 19995-2015 are taken from UNCTADStat database (UNCTADStat. (n.d.).). The selected database makes possible the analysis of import and sector competitiveness of word processing industry in Serbia on domestic and global markets according to SITC Revision 3 International Trade Classification of Products.

The calculation of statistical variables for measuring competitiveness of wood processing industry was done by using MS Excel, created for this purpose. The competitiveness of wood processing industry in Serbia was done by using appropriate statistical methods. The dependence of selected data was analysed by statistical methods of correlation analysis. The intensity and direction of mutual dependence between the selected variables was analysed by calculation correlation coefficient ( $r$ ).

The obtained data were classified in statistical series and analysed in order to identify the structure and mutual influences of the elements of the structure. The aim of statistical analysis was targeted towards identification of "frequency distribution", i.e. identification of frequency pattern of the occurrence of certain numerically expressed properties. Statistical, including correlation analysis was used, which identified the presence and substantial characteristics of relations between data and groups of data, respectively. Correlation analysis does not explain all features of the identified relations; it only informs on the presence of their frequency.

\section{Research results}

Measuring competitiveness of wood processing industry starts from the capability of domestic enterprises to successfully sell their products on domestic and foreign markets, in the conditions of fair competitive contest with the enterprises from other countries which operate in the sector of wood industry, by using production factors more efficiently and adapting the surrounding factors more successfully, i.e. better recognising and more favourably satisfying the needs of domestic and foreign customers.

The selection of indices of competitiveness at the level of wood processing industry is defined by the efforts to find the answer to the question whether 
Milićević S. et al.:The Competitivenes of Wood Processing Industry in the Republic of..

wood processing industry in Serbia is competitive on domestic and foreign markets. The proof of competitiveness is larger quantity of domestic products that are placed on foreign markets than the scope of foreign products in the same sector of wood processing industry that are placed on domestic market. The information on these facts can be obtained by calculating the coefficients RCA, RCA1 and RCA2, as well as the coefficients CTB, GLI and MI. Time series analysis of the indicators of competitiveness shows the change of competitiveness of wood processing industry in Serbia in the sense of its increase or decrease in the observed time interval of twenty years (Table 2).

Table 2: Indicators of competitiveness of wood processing industry in Serbia in the period 1995-2015

\begin{tabular}{|c|c|c|c|c|c|c|c|c|c|c|}
\hline $\begin{array}{c}\text { Indicator } \\
\text { /Year }\end{array}$ & $\mathbf{1 9 9 5}$ & $\mathbf{2 0 0 0}$ & $\mathbf{2 0 0 5}$ & $\mathbf{2 0 1 0}$ & $\mathbf{2 0 1 1}$ & $\mathbf{2 0 1 2}$ & $\mathbf{2 0 1 3}$ & $\mathbf{2 0 1 4}$ & $\mathbf{2 0 1 5}$ & Average \\
\hline RCA & 0,7268 & 0,870 & 0,463 & 0,650 & 0,761 & 0,847 & 0,710 & 0,810 & 0,891 & 0,722 \\
\hline RCA1 & 2,3124 & 3,064 & 1,724 & 2,304 & 2,512 & 2,643 & 2,293 & 2,324 & 2,419 & 2,119 \\
\hline RCA2 & 0,1335 & 0,096 & $-0,083$ & 0,057 & 0,119 & 0,161 & 0,182 & 0,236 & 0,284 & 0,047 \\
\hline MI & 0,0291 & 0,037 & 0,012 & 0,017 & 0,020 & 0,023 & 0,018 & 0,022 & 0,025 & 0,025 \\
\hline CTB & 0,8730 & 1,273 & 0,762 & 0,656 & 0,630 & 0,654 & 0,434 & 0,433 & 0,442 & 0,936 \\
\hline GLI & 0,6518 & 0,590 & 0,772 & 0,686 & 0,637 & 0,600 & 0,659 & 0,616 & 0,582 & 0,657 \\
\hline
\end{tabular}

Source: Calculated by the author, based on the data obtained from UNCTADStat, n.d.

The average value of RCA index in the period $1995-2015$ was 0.722 . In all years, the values of TCA index were positive, which points to comparative advantage of wood processing industry on the domestic market.

The index of growth of competitiveness RCA1 is higher than one (the average value was 2.1189). This points to high competitiveness of Serbian wood processing industry on the international market, while increasing values of indicators after 2006 point that uncovered competitive advantage during the last ten years increased after a significant fall in the period 1998-2006.

Positive values of the indication of trade exchange (RCA2) in the period 9952015 (the average value of RCA 2 was 0.473 ) show positive contribution of wood processing industry in foreign exchange balance of economy (Figure 2). 
Milićević S. et al.:The Competitivenes of Wood Processing Industry in the Republic of..

Figure 2: The change of values of indicators $R C A, R C 1$ and $R C 2$ for wood processing industry in Serbia in the period 1995-2015

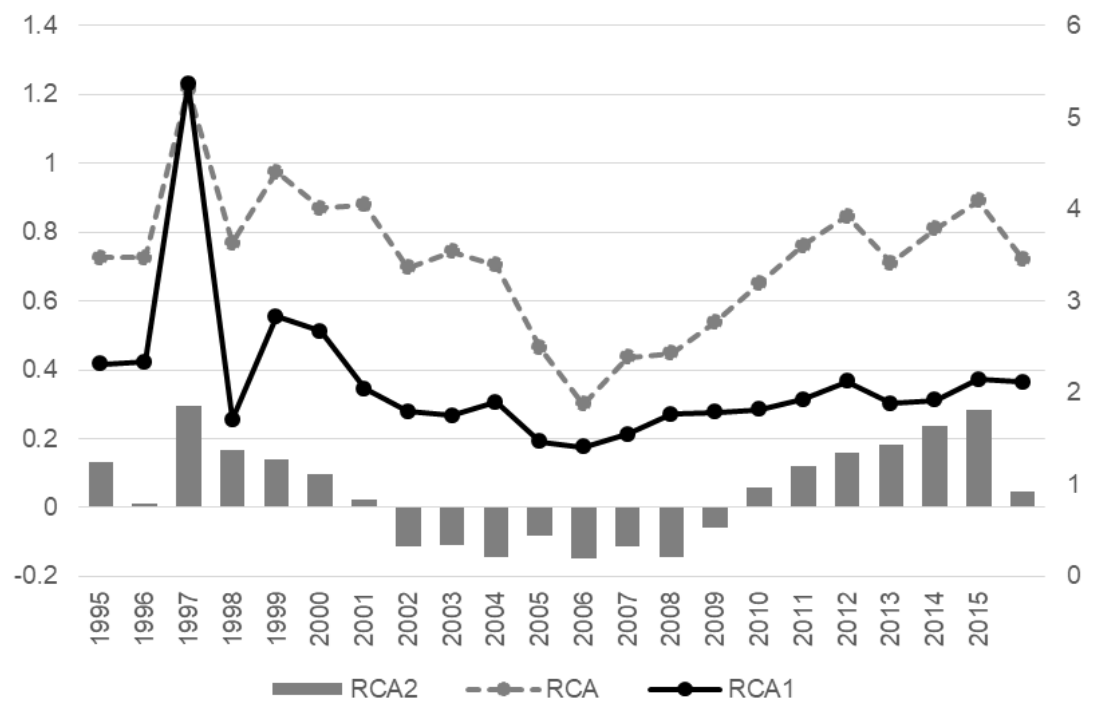

Source: Calculated by the author, based on the data obtained from UNCTADStat, n.d.

The indicator of net trade exchange (RCA2) is connected with the index of contribution to trade balance (CTB) which points to the contribution of the sector in formation of active national trade balance and growth of economy.

The average value of CTB index of wood processing industry (CTB=0.9362) and positive annual values of CTB of wood industry show that the contribution of the sector in total trade balance was positive and that real surplus exceeded the expected, hence relative deficit was lower than the expected, which was especially visible in the period 1996-2004.

The values of GLI firstly showed high and then decreasing level of presence of the wood procession industry products in intersectoral foreign exchange. This points to the loss of capabilities of the sector to create surplus of national trade balance (the average value of GLI index of wood processing industry in Serbia is 0.657).

The average $(\mathrm{Ml}=0.0254)$ and positive annual values of Michaely index confirmed the competitiveness of domestic wood processing industry, as well as its low specialisation as a whole, especially after 2004 (Figure 3). 
Milićević S. et al.:The Competitivenes of Wood Processing Industry in the Republic of..

Figure 3: The change of values of indicators CTB, GLI and MI for wood processing industry in Serbia in the period 1995-2015

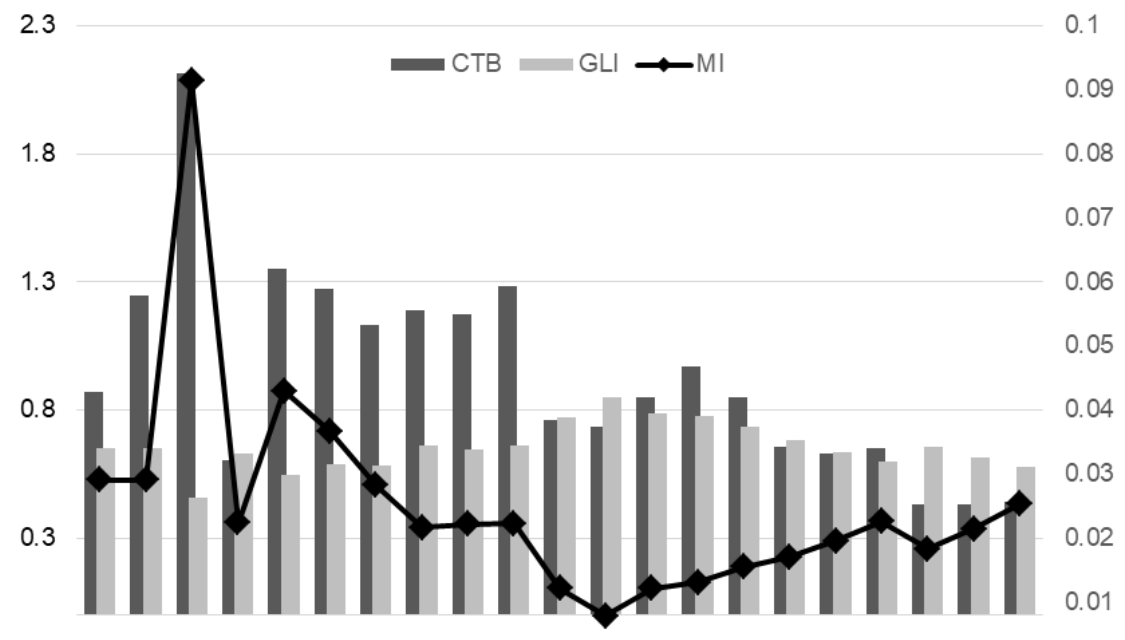

$-0.2$

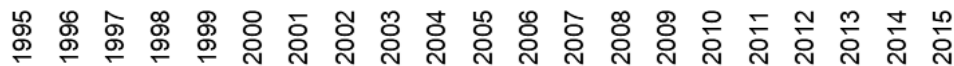

Source: Calculated by the author, based on the data obtained from UNCTADStat, n.d.

The average value of all observed competitiveness indicators for the given period is shown in Figure 4.

Figure 4: Average values of indicators of competitiveness of wood processing industry in Serbia

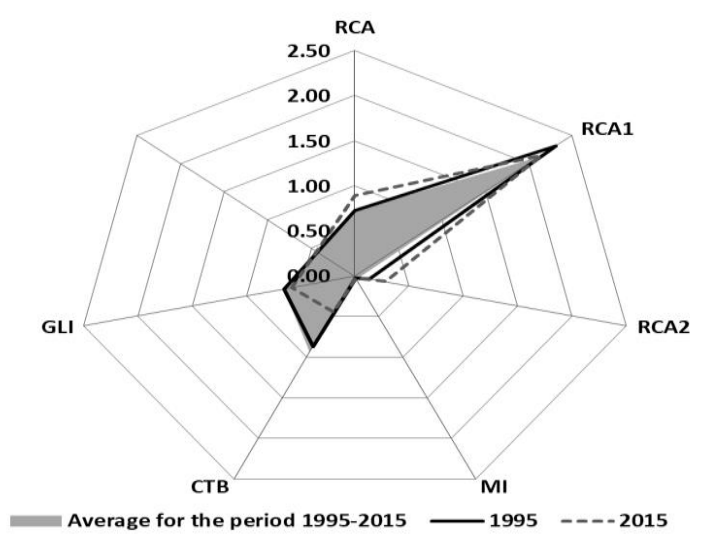

In order to reveal the factors which influence comparative advantages of wood Industrija, Vol.45, No.3, 2017 
Milićević S. et al.:The Competitivenes of Wood Processing Industry in the Republic of..

processing industry in Serbia, the correlation coefficients were calculated by using the method of correlation analysis; their values showed the degree of dependence between the selected indicators of competitiveness of wood industry in Serbia (Table 3).

Table 3: Coefficients of correlation

\begin{tabular}{|l|l|l|l|l|l|}
\hline Correlation & \multicolumn{5}{|c|}{$y$} \\
\hline $\mathrm{x}$ & RCA & RCA1 & RCA2 & CTB & Ml \\
\hline MI & 0,8228 & 0,9869 & 0,5473 & 0,7647 & \\
\hline GLI & $-0,9985$ & $-0,7415$ & $-0,7554$ & $-0,4281$ & $-0,7946$ \\
\hline Exoport WPI & 0,7450 & 0,9830 & 0,4615 & 0,8149 & 0,9897 \\
\hline RCA & & 0,7726 & 0,7556 & 0,4551 & 0,8228 \\
\hline
\end{tabular}

\section{Discussion}

Although positive, declining values of RCA index in the period 1996-2006 point to decrease of comparative competitiveness of domestic wood processing industry, the increasing values of RCA index after 2006 show that the comparative advantage of domestic wood processing industry gradually increased on the international market, which was followed by permanent increase of export after its fall in 2008.

The previous results were confirmed by the average value and flow of values of RCA1 index. The obtained values of this indicator point to relatively high and increasing competitiveness of Serbian wood processing industry on the international market after 2006. Positive movements in the last ten years were preceded by a significant decline of international competitiveness of domestic wood processing industry in the period 1998-2006.

Positive average value of indicators of net trade exchange (RCA2) in the period 1995-2015 show positive contribution of wood processing industry to foreign exchange balance of economy. Observed by years, positive contribution of wood processing industry to foreign exchange balance of economy was recorded in the period 1995-2001 and 2010-2015, while negative was in the period 2002-2009, since the recorded deficit of wood processing industry in this period had negative effect on total foreign trade balance of domestic economy.

The index of trade balance shows that the contribution of the sector of wood industry in total trade balance was positive and that real surplus exceeded the expected, while relative deficit was lower than expected, which was especially visible in the period 1996-2004, with constant decrease after 2008. 
Milićević S. et al.:The Competitivenes of Wood Processing Industry in the Republic of..

From 2005 to 2015, GLI permanently decreased, to be more precise, from 0.772 to 0.582 . This points to the necessity of change of structure in wood processing industry in the Republic of Serbia, and turn of its part towards more pronounced specialisation within certain product groups with higher value added, which could thus lead to the increase of GLI. The countries with higher Grubel-Lloyd index have significantly higher productive differentiation and higher production growth due to the economy of scope. Significant increase of participation of intraindustrial trade in total trade would imply sustainable industrial development and decrease of technological gap in relation to more developed countries.

The change of $\mathrm{MI}$ shows the level of specialisation of production in wood processing industry of Serbia after 2006. However, the accomplished specialisation of production in 2015 was still under the level of specialisation achieved in the period before 2001.

The results of analysis of dependence between the selected indicators by using the method of statistical correlation shows that the competitiveness of the sector of wood processing industry is strongly influenced by the following factors:

- The level of specialisation of counties in products of sector

- High level of intersectoral foreign trade exchange of a country

- Exporting performances of the sector at national level

- The participation of sector in export of a country which has mainly positive contribution of the sector to active foreign trade balance of the country

Since the investigation of competitiveness in the domain of wood processing industry is insufficiently focused on the means by which the enterprises in this sector can improve activities which create higher value added, thus increasing their competitiveness, the development of those activities within the chain of values still remains the basis for improvement of total competitiveness of enterprises in wood processing industry in both Serbia and world.

Bearing in mind the fact that wood processing industry is a group of complementary but mutually technologically different activities (from production of raw materials based on intensive utilisation of natural resources to manufacturing of complex products of high value added) with diverse roles in the chain of value, it follows that various activities have various bearers of competitiveness. Therefore, the establishment of long-term competitiveness in the domain of wood processing industry cannot depend on the exploitation of natural resources only, but has to be increasingly based on production and market realisation of technologically complex products and services with higher value added, which count on intensive exploitation of natural resources (various types of wood assortment) only in their basis. 
Milićević S. et al.:The Competitivenes of Wood Processing Industry in the Republic of..

\section{Conclusion}

The results of quantitative analysis of development and position, i.e. competitiveness of wood processing industry in Serbia in the period 19952015 show that this segment of manufacturing has a certain comparative advantage on both domestic and international markets, and that after a decade of regression, it continually increased in the last ten years. The competitiveness of wood processing industry in Serbia originates from its capability to generate surplus in the exchange with other countries of the world.

The research also confirmed competitive capabilities and pointed to developmental potential of wood industry in Serbia, competitive potential of manufacturer of wood products (especially furniture) on domestic and international market and its capability to increase the scope and quality of offer, thus contributing better and more significantly to sustainable growth of national economy and balancing international trade.

The results of research show that competitiveness of wood processing industry increases with the growth of net export value and that specialisation of a country in foreign trade exchange positively influences the creation of positive balance through manufacturing the products with higher value added.

The analysis of competitiveness showed that the structure of product exchange in wood processing industry of Serbia was positive, because the greatest part of export included the products with higher value added (furniture). The trends were also positive, since they pointed to further strengthening of export performances of the products with higher value added. However, still insufficient specialisation of Serbia in the production and export of wood industry, relatively modest possibilities to actively contribute to improvement of trade balance with foreign countries pointed to a great need and possibilities for further strengthening of existing and establishment of new comparative advantages of wood processing industry on domestic and foreign markets, and increasing focus on strengthening competitiveness through the manufacturing of products with higher stages of finalisation and higher values added.

Finally, starting from the presentation of current conditions, speed and direction of changes, it is necessary to expand the current research and conduct scientific investigations which will be directed towards the optimisation of productive and exporting structure of wood industry processing, aimed at further increase of competitiveness of wood industry in Serbia. 
Milićević S. et al.:The Competitivenes of Wood Processing Industry in the Republic of..

\section{References}

Aiginger, K.; \& Landesmann, M. (2002). Competitive Economic Performance: The European View, WIFO Working Papers 179/2002, Vienna: Austrian Institute of Economic Research

Amighini, A., Leone, M., \& Rabellotti R. (2011). "Persistence versus Change in the International Specialization Pattern of Italy: how much does the 'Direct Effect' Matter?", in Regional Studies 45, pp. 381-401.

Annoni, P., \& Kozovska, K. (2010). EU Regional Competitiveness Index 2010 JRC Scientific and Technical Reports. European Commission Joint Research Centre Institute for Security and Protection of the Citizens, Luxemburg.

Balassa, B. (1965). Trade liberalisation and "revealed" comparative advantage. The manchester school, 33(2), 99-123.

Cho, D., \& Moon, H. (2000) From Adam Smith to Michael Porter: Evolution of Competitiveness Theory. Singapore: World Scientific Publishing Co. Pte. Ltd.

Dieter, M., \& Englert, H. (2007). Competitiveness in the global forest industry sector: an empirical study with special emphasis on Germany. European Journal of Forest Research, 126(3), 401-412

Garelli, S. (2004.) Competitiveness of Nations: The Fundamentals, IMD World Competitiveness Yearbook, Lausanne, Switzerland, str. 730-742.

Grauwe, D., P. (2010), Dimensions of Competitiveness, The MIT Press, http://mitpress.mit.edu.

Grubel, Herbert G., \& Peter J. Lloyd. (1971), The Empirical Measurement of IntraIndustry Trade, Economic Record 47 (120), 494-517.

Han, X., Wen, Y., \& Kant, S. 2009: The global competitiveness of the Chinese wooden furniture industry. Forest Policy and Economics 11(8): 561-569.

Hinloopen, J., \& Marrewijk., C. (2001), On the empirical distribution of the Balassa index, Weltwirtschaftliches Archiv / Review of World Economics 137 (1): 1-35.

Kitson, M., Martin, R., \& Tyler, P. (2004). Regional competitiveness: an elusive yet key concept?. Regional studies, 38(9), 991-999.

Klodt, H. (1993) 'Europäische Industriepolitik nach Maastricht', Weltwirtschaftliches Archiv. $263 \mathrm{ff}$

Melišek, I. (2012). Meranie a hodnotenie makroekonomických výsledkov zahraničného obchodu. Ekonomické rozhlady, 41(4), 439-451.

Michaely, M. (1962). Multilateral balancing in international trade. The American Economic Review, 52(4), 685-702

Porter, M., E. (2007). Konkurentska prednost - osvarivanje $i$ očuvanje vrhunskih poslovnih rezultata. ASEE Books. Novi Sad, str. 22-30.

Rybakovas, E. (2009). Competitiveness of Lithuanian manufacturing industry, Economics and management, (14), str. 912-918.

Siggel, E. (2007). International Competitiveness and Comparative Advantage: $A$ Survey and a Proposal for Measurement, CESifo Institute, German.

Standard International Trade Classification - SITC Revision 3

Sujová, A., Hlaváčková, P., \& Marcineková, K. (2015). Measuring the Impact of Foreign Trade on Performance Growth of the Woodprocessing Industry. Wood Research, 60(3), 491-502. 
Milićević S. et al.:The Competitivenes of Wood Processing Industry in the Republic of..

Toming, K. (2011). The impact of integration with the European Union on the international competitiveness of the food processing industry in Estonia. Dissertation, Estonia: Tartu University Press.

Trade Indicators - World Integrated Trade Solution (WITS). (n.d.). Retrieved July 13, 2017, from http://wits.worldbank.org/WITS/WITS/WITSHELP/Content/Utilities/e1.trade indi cators.htmWorldbank

UNCTADStat. (n.d.). Retrieved July 12, 2017, from

http://unctadstat.unctad.org/wds/TableViewer/tableView.aspx?Reportld=24738 